\title{
Radioactive Iodine Therapy Room a Part University Hospital of the Actual Conditions of Safety Management Consideration
}

\author{
Sanghyun Han, Sangho Lee
}

Seonam University

\section{일부 대학병원 방사성옥소 치료병실의 안전관리로 본 실태 고찰}

\author{
한상현, 이상호
}

서남대학교 방사선학과

\begin{abstract}
Using Radioiodine therapy of thyroid cancer in the past have been used for decades as many look forward to continuing treatment be used, and the current outlook of in korea 2010 based on the number of Iodine therapy room is operated by 124 , but still is lacking. So many hospitals opened their therapy room, but importantly, increasing number of treatment rather than therapy room current treatment is that it must be preceded by the proper administration of the. Therefore therapy room expansion, discussions about before now being applied therapy room safety management standards, and a part university hospital based safety management standards by examining how well kept and that the therapy room to the use of the overall safety management research on the actual condition were discussed.
\end{abstract}

Key Words : Therapy Room, Thyroid Cancer, Safety Management

\section{요야}

방사성옥소를 이용한 갑상선 암의 치료는 지난 수 십년 동안 사용되어 왔으며 많은 치료효과를 보이면서 앞으로 지 속적으로 사용되어 질 전망이고 현재 우리나라의 옥소치료병실 수는 2010 년 기준 124 개의 치료병실이 운영되고 있으 나 아직도 부족한 실정이다. 그래서 많은 병원들이 치료병실을 개설하고 있으나 중요한건 치료병실의 수적 증가보단 현재 치료병실의 올바른 관리가 선행되어야 한다는 것이다. 따라서 병실증설에 대한 논의에 앞서 현재 적용되고 있는 치료병실의 안전관리 기준과 일부 대학병원에서 기준으로 삼고 있는 안전관리기준을 조사하여 얼마나 잘 지켜지고 있 는지, 치료병실의 이용에 따른 전반적인 안전관리실태여부를 조사하여 고찰 하였다.

중심단어 : 치료병실, 갑상선 암, 안전관리 


\section{I. 서론}

최근 의학 및 의용공학의 발전으로 방사선을 이용 한 진단 기술의 발전과 건강에 대한 국민의 의료 욕구 가 증가함에 따라 방사선을 이용한 질병의 진단과 치 료방법의 새로운 기법이 개발되고 있고 그 이용은 지 속적으로 매년 증가되는 추세이다 ${ }^{[1]}$. 갑상선 암의 원 인은 명확하지 않지만 발병률을 높이는 인자로 방사 선에 대한 노출, 가족의 유전적 요인, 과거 갑상선 질 환 병력 등이 보고되고 있다. 최근 발표한 2009년 국가 암 등록 통계에서 우리나라의 암 발생률 통계를 보면 1999년부터 2009년 까지 10년 동안 가장 빠르게 증가 하고 있는 암이 갑상선 암으로 2009년 남녀 전체 가장 많이 발생한 암은 갑상선 암이다 ${ }^{[2]}$. 특히 여자에서 모 든 암 93,337 명 중 갑상선 암이 26,815명으로 전체 암 중 $28.7 \%$ 로 1 위를 차지하였다. 이는 앞서 말한 갑상선 암의 인자들과 환자들의 건강에 대한 높은 인식과 각 종 의료기기의 발달, 갑상선 초음파 검사의 회수 등이 높아짐에 따라 암의 진단 확률도 높아지고 있는 추세 이다. 이에 대해 갑상선 암 환자가 늘어난 것에 대해 논란이 있지만 어떤 이유든지 이로 인한 방사성옥소 치료환자는 앞으로 증가 할 것으로 보인다 ${ }^{[3]}$.

지난 해 발생된 후쿠시마 원자력발전소 폭발로 인 해 우리나라에서도 원자력에 이용에 대해 관련법규를 통해 관리면에서 강화되고 있는 것이 사실이다. 특히 의료이용분야에서 갑상선 암의 치료에 이용되는 ${ }^{131} \mathrm{I}$ 의 사용은 다른 선원에 비해 1 회 투여되는 용량이 많고 체내피폭까지 고려해야하기 때문에 무엇보다 관리 면 에서 중요하다. ${ }^{131} \mathrm{I}$ 의 사용은 현재 원자력안전기술원 에서 취득부터 사용, 폐기 까지 모두 관리 하고 있지 만 옥소치료병실을 사용함에 있어서 세세한 부분까지 는 관리, 감독하기는 힘든 실정이다.

따라서 현재 적용되고 있는 치료병실의 안전관리 기준과 일부 대학병원에서 기준으로 삼고 있는 안전 관리기준을 조사하여 얼마나 잘 지켜지고 있는지, 치 료병실의 이용에 따른 전반적인 관리상태는 어떠한지, 환자에게는 보다 안전하고 편안한 치료가 될 수 있도 록 개선방안을 제시하고 방사선작업종사자에게는 방 사선피폭을 최소화 할 수 있는 방안과 각 병원들간 치
료병실관리의 효율적인 관리 방법에 대해 고찰 하고 자 한다.

\section{1. 방사성 옥소치료}

${ }^{131} \mathrm{I}$ 의 반감기는 8 일이며 감마선과 베타선을 방출하 는데 ${ }^{[4]}$ 체내에 잔존해 있는 갑상선 암세포로 방사성옥 소가 능동적으로 섭취되어 ${ }^{131}$ I로부터 방출되는 베타선 이 치료에 이용된다.

따라서, 방사성옥소치료란 갑상선기능항진증이나 갑상선 암으로 인한 절제 수술을 받은 환자를 대상으 로 ${ }^{131} \mathrm{I}$ 을 알약으로 만들어 환자에게 적절한 용량을 투 여하여 체내에 잔존해있는 갑상선 암 조직 및 전이 암 조직을 제거하기 위한 치료방법이다.

\section{2. 옥소치료병실 관련규정}

갑상선암 치료에 이용되는 옥소는 방사성동위원소 로서 원자력안전위원회의 허가를 받아야 사용할 수 있고 한국원자력안전기술원(KINS)으로부터 시설검사 에 합격해야 옥소치료병실을 운영할 수 있다. 또한 옥 소치료병실은 방사선관리구역으로 치료병실 외부 방 사선량률이 1 주당 $400 \mu \mathrm{Hs}$ 를 넘지 않아야 한다.

실제로 방사성옥소치료 방법은 간단하나 중요한 것 은 환자가 먹은 ${ }^{131} \mathrm{I}$ 이 체내에서 모두 사라질 때까지는 환자 자체가 방사선원이기 때문에 환자 주위의 일반 인들을 방사선 피폭으로부터 보호해야 한다는 것이다. 우리나라의 원자력안전법에는 ${ }^{131} \mathrm{I}$ 을 이용한 입원, 퇴 원의 기준 선량이 명확하게 고시되지 않아 통상적으 로 방사선 방호에 관한 국제 기본 안전기준(IAEA BSS) 과 US NRC의 규정을 따른다 ${ }^{[3]}$. 따라서 납으로 차폐된 특수 설계되어진 격리병실에서 격리 시켜 입원치료 하게 되고, 보통 입원치료를 받게 되는 용량은 $1,110 \mathrm{MBq}(30 \mathrm{mCi})$ 이상의 고용량 ${ }^{131} \mathrm{I}$ 을 투여 받은 환자 로 짧게는 1 박 2 일에서 길게는 3 박 4 일 동안 입원하게 된다. 투여 받은 환자로 인하여 다른 개인의 유효선량 이 $5 \mathrm{mSv}$ 를 초과할 가능성이 있는 경우 환자를 격리시 켜 입원한다 ${ }^{[5]}$.

또한, 치료병실에서 환자가 사용한 물품의 폐기물 은 방사성폐기물로 취급되어 일정기간동안 보관해 자 연붕괴 되도록 하여 기준치 이하가 되면 자체 및 위탁 
"Journal of the Korean Society of Radiology, Volume 6, Number 5"

폐기 하도록 하고 있고, 환자가 방사성옥소를 섭취하 면 잔존해있는 갑상선 암세포로 섭취하고 나머지는 소변으로 배출된다. 따라서 치료병실내에 전용화장실 을 갖추어 환자가 사용한 물을 따로 보관토록 하여 환 경보호측면에서 배출허용기준치 $3 \times 10^{4} \mathrm{~Bq} / \mathrm{m}^{3}$ 이하가 되 도록 규정하고 있다(Table 1).

Table 1. Management standards of Therapy Room

\begin{tabular}{|c|c|}
\hline 구분 & 치료병실 관리 기준 \\
\hline 환자 퇴원 시 기준유효선량 & $5 \mathrm{mSV}$ \\
\hline $\begin{array}{c}\text { 배수 중 배출허용 } \\
\text { 기준치 }\end{array}$ & $3 \times 10^{4} \mathrm{~Bq} / \mathrm{m}^{3}$ \\
\hline 외부 방사선량률 & $400 \mu \mathrm{SV} / \mathrm{w}$ \\
\hline
\end{tabular}

\section{3. 우리나라 옥소치료병실 현황}

한국동위원소협회에서 발표한 2010년도 방사선 이 용 통계자료 ${ }^{[6]}$ 에 따르면 전국의 방사성옥소 치료병실 은 124 개, 환자들의 평균 대기 일 수는 4.3 개월이다. 서 울의 경우 환자의 선택적 진료와 치료로 인해 6개월에 서 1 년을 기다려야 하며 지방은 보통 3.5 개월에서 1 년 정도 기다려야 치료를 받을 수 있다(Table 2).

Table 2. Status of Therapy Room

(unit: Number)

\begin{tabular}{|c|c|c|c|}
\hline 구분 & 2008년 & 2009년 & 2010년 \\
\hline 치료병실 보유 기관수 & 43 & 50 & 56 \\
\hline 치료 병실 수 & 85 & 105 & 124 \\
\hline
\end{tabular}

이렇듯 갑상선 암의 발생률은 급속도로 증가하고 있고 그에 필요한 방사성옥소치료병실도 증가하고 있 는 추세이지만 아직도 부족한 실정이다. 이로 인하여 많은 대형병원들이 방사성옥소치료병실 수를 늘려 운 영을 하고 있고 또한 계획을 가지고 있으나 치료병실 을 개설하려면 시설에 필요한 비용이 많이 들고 환자 가 1 인실을 사용함에도 불구하고 6 인실 정도의 병실수 가 정도만 인정하고 있어 ${ }^{[7]}$ 모호한 부분들이 많은 실 정이다. 그리고 개설 후 치료병실을 사용함에 있어 치 료병실의 전반적인 관리 또한 관련법에 따라 적용되 어 진다. 따라서 방사성옥소치료가 증가추세인 만큼
그로인한 위험도 또한 많아진다는 것을 간과하지 말 아야 한다. 그렇기 때문에 현재 사용하고 있는 방사성 옥소치료병실의 관리를 어떻게 하느냐 또한 중요한 문제라 인식된다.

\section{4. 옥소치료병실의 조사대상 및 방법}

\section{1) 조사대상}

현재 방사성옥소치료병실의 관리상태를 조사하고자 대전, 충남지역 대학병원 중 방사성옥소 치료병실을 보유한 병원은 5 곳으로 모두 적법한 절차를 거쳐 운영 중에 있었다. 따라서 갑상선 암 제거 수술을 받고 고 용량 방사성 옥소치료를 받은 환자들이 사용한 치료 병실과 치료병실의 관리 상태를 조사대상으로 하였다.

\section{2) 조사방법}

연구자가 5 곳의 대학병원 핵의학과 책임자와 면담 하여 설문 조사를 실시하였고 조사목적은 현재 적용 되고 있는 치료병실의 안전관리 기준과 일부 대학병 원에서 기준으로 삼고 있는 안전관리기준을 조사하여 얼마나 잘 지켜지고 있는지, 치료병실의 이용에 따른 전반적인 안전관리 상태 여부를 조사하였다. 구제적인 조사내용은 핵의학과 방사선사의 인력현황, 옥소치료 병실의 운영현황, 폐수 및 폐기물의 안전관리현황, 방 사성 옥소 투 여시 안전관리 시행 현황, 방사성옥소치 료병실 청소시 안전관리 시행 현황, 환자가 퇴원 가능 한 유효선량 기준에 대해 조사 하였다.

\section{3) 조사 후 평가}

조사대상을 현재 규정되어 있는 기준과 비교하여 과연 잘 이루어지고 있는지? 이루어지지 않다면 그 이 유는 무엇인지? 대안 방안은 없는 것인지?를 고찰 하 였다.

\section{II. 옥소치료병실 운영 및 관리 현황}

\section{1. 핵의학과 방사선사의 인력 현황}

현재 방사성옥소치료는 핵의학과에서 주도적으로 
시행되고 있는데 대전, 충남지역 핵의학과에서 근무하 는 방사선사의 인력 특성은 table 3.과 같다. 각 대학병 원 핵의학과에 근무하는 방사선사는 평균 5.2 명으로 특히 A병원에선 여자 방사선사가 근무하고 있었다. A 병원의 여자는 가임 여성으로 태아는 성인보다 방사 선에 민감하고 기형 발생의 우려가 있기 때문에 임신 이 확인된 시점부터 출산까지 하복부 표면에서의 등 가선량한도를 $2 \mathrm{mSv}$ 로 권고하고 있고, ${ }^{131} \mathrm{I}$ 은 내부피폭 의 우려도 있기 때문에 연간섭취한도의 $1 / 20$ 로 한다. 만약 임신사실을 알았다면 좀 더 적극적인 방호대책 이 필요 하다. 그리고 임신 초기에는 임신사실을 인지 하지 못하는 경우가 있기 때문에 치료병실관리에서 여성 방사선사가 직접 옥소를 투여하고 청소하는 등 전반적인 치료병실관리에서 피폭에 대한 배려도 필요 하다.

Table 3. Personnel status of radiologist department of nuclear medicine

(unit: number)

\begin{tabular}{|c|c|c|c|c|c|c|c|}
\hline 특성 & 구 분 & $\begin{array}{c}\text { A } \\
\text { 병원 }\end{array}$ & $\begin{array}{c}\text { B } \\
\text { 병원 }\end{array}$ & $\begin{array}{c}C \\
\text { 병원 }\end{array}$ & $\begin{array}{c}\text { D } \\
\text { 병원 }\end{array}$ & $\begin{array}{c}E \\
\text { 병원 }\end{array}$ & 계 \\
\hline \multirow{2}{*}{ 성별 } & 남 & 3 & 5 & 8 & 4 & 4 & 24 \\
\hline & 여 & 2 & . & . & . & . & 2 \\
\hline \multirow{4}{*}{ 연령 } & 20-29세 & 3 & 2 & 3 & & . & 8 \\
\hline & 30-39세 & 2 & . & 1 & 1 & 2 & 6 \\
\hline & 40 49세 & . & 2 & 4 & 3 & 2 & 11 \\
\hline & 50 세 이상 & . & 1 & . & . & . & 1 \\
\hline \multirow{3}{*}{ 학력 } & 전문대졸 & 1 & 2 & 4 & 3 & 2 & 12 \\
\hline & 대학교졸 & 3 & 2 & 3 & . & . & 8 \\
\hline & $\begin{array}{c}\text { 대학원 } \\
\text { 이상 }\end{array}$ & 1 & 1 & 1 & 1 & 2 & 6 \\
\hline \multirow{4}{*}{$\begin{array}{l}\text { 근무 } \\
\text { 경력 }\end{array}$} & 5년 미만 & 3 & 2 & 4 & . & 1 & 10 \\
\hline & 6 10년 & 1 & . & 1 & 1 & 2 & 5 \\
\hline & 11 15년 & 1 & . & 1 & . & . & 2 \\
\hline & 16년 이상 & . & 3 & 2 & 3 & 1 & 9 \\
\hline 결혼 & 기혼 & 3 & 2 & 4 & 4 & 3 & 16 \\
\hline 여부 & 미혼 & 2 & 3 & 4 & . & 1 & 10 \\
\hline \multicolumn{2}{|r|}{ 계 } & 5 & 5 & 8 & 4 & 4 & 26 \\
\hline
\end{tabular}

\section{2. 옥소치료 병실의 운영 현황}

옥소치료병실은 5 개 대학병원에서 총 13 개의 병실 이 운영되고 있었고 치료병실의 운영기간은 짧게는 1 년 이내 길게는 10 년 정도의 운영기간을 보였다(Table 4). 치료병실의 주당 이용횟수는 보통 일주일에 2 박 3 일 로 2 회 내지 3 회에 걸쳐 운영되고 있었다. 특히 주당 3 회에 걸쳐 운영되고 있는 병원은 3 곳으로 환자가 많아
병실 회전율을 높이고 있는 것으로 보여지나 치료병 실관리 측면에서 시간적인 여유가 충분치 않아 종사 자들의 업무의 가중이 높을 것으로 보인다. 치료병실 관리의 주 담당부서는 거의 모든 병원이 핵의학과에 서 담당하고 있었으나 C병원은 병동에서 관리를 하고 있었다. 이는 방사선에서 대해 잘 모르는 병동직원들 이 관리하며 생길 수 있는 방사선 안전관리에 대해 심 각하게 생각해 봐야 한다. 물론 치료병실을 관리하는 병동직원이 종사자교육을 받고 이를 행한다면 법적으 로 아무런 문제가 없다. 하지만 조사결과 C병원 병동 직원은 출입자로 등록되어 있지 않아 출입자관리와 치료병실관리에 허점이 발견되었고 특히 방사선 안전 관리자가 있고 치료병실 관리에 대한 매뉴얼도 있으 면서 이를 지키지 않는다는 것은 병실관리가 제대로 시행되고 있지 않음을 알 수 있다. 물론 각 병원별로 치료병실에 대한 특성은 존재한다. 핵의학과 인력 규 모라든지, 검사건수, 기타 직무 특성에 따라 관리가 다 를 순 있다.

이에 대해 방사선 안전관리자는 병원과 함께 치료 병실관리에 대해 보다 적극적인 노력이 요구되고 병 원 특성상 병동에서 치료병실관리가 이루어 진다면 방사선피폭에 대한 교육을 철저히 하여 환자와 본인, 주변인에게 방사선피폭이 없도록 해야 한다.

Table 4. Operating status of lodine Therapy room

(해당되는 곳에 $\vee$ 표시)

\begin{tabular}{|c|c|c|c|c|c|c|}
\hline 특 성 & 구 분 & $\begin{array}{l}\text { A } \\
\text { 병원 }\end{array}$ & $\begin{array}{l}\mathrm{B} \\
\text { 병원 } \\
\end{array}$ & $\begin{array}{l}\text { C } \\
\text { 병원 } \\
\end{array}$ & $\begin{array}{l}\text { D } \\
\text { 병원 }\end{array}$ & $\begin{array}{l}\mathrm{E} \\
\text { 병원 } \\
\end{array}$ \\
\hline \multicolumn{2}{|l|}{ 1. 치료병실의 운영기간(년) } & 10 & 1 & 8 & 7 & 8 \\
\hline \multicolumn{2}{|c|}{ 2.치료병실의 보유 병실 수(개) } & 5 & 2 & 2 & 2 & 2 \\
\hline \multicolumn{2}{|c|}{ 3.치료병실의 주당 이용횟수(회) } & 3 & 2 & 3 & 2 & 3 \\
\hline \multirow{2}{*}{$\begin{array}{l}\text { 4. 치료병실관리의 } \\
\text { 주담당부서 }\end{array}$} & 핵의학과 & 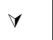 & $\checkmark$ & & 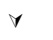 & $\checkmark$ \\
\hline & 병동 & & & y & & \\
\hline \multirow{2}{*}{$\begin{array}{l}\text { 5. 방사선안전관리자의 } \\
\text { 유무 }\end{array}$} & 있다 & 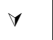 & 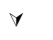 & 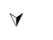 & 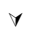 & 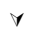 \\
\hline & 없다 & & & & & \\
\hline \multirow{2}{*}{$\begin{array}{l}\text { 6. 치료병실관리에대한 } \\
\text { 매뉴얼 }\end{array}$} & 있다 & 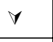 & 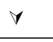 & v & 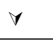 & 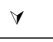 \\
\hline & 없다 & & & & & \\
\hline \multirow{2}{*}{ 7. 치료병실전담인력 } & 있다 & 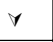 & $\checkmark$ & & & $\checkmark$ \\
\hline & 없다 & & & v & y & \\
\hline \multirow{2}{*}{$\begin{array}{l}\text { 8.치료병실 최초 출입시 } \\
\text { 병실에대한 안전관리교육 }\end{array}$} & 받았다 & 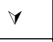 & 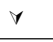 & y & 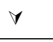 & 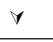 \\
\hline & 안받았다 & & & & & \\
\hline
\end{tabular}


"Journal of the Korean Society of Radiology, Volume 6, Number 5"

\section{3. 폐기물 및 폐수의 관리 현황}

\section{1) 방사성 폐기물}

방사성폐기물이란 방사성물질 또는 그에 따라 오염 된 물질로서 폐기의 대상이 되는 물질을 말한다. 따라 서 치료병실에서 환자가 사용한 물품이 오염이 되었다 면 이도 방사성폐기물이 되는 것이다. 원칙적으로 방 사성폐기물은 허용기준치 이상이 되면 따로 보관하여 폐기하도록 되어있다. 그렇다고 해서 환자가 사용한 모든 물품을 폐기 할 순 없다. 만약 모두 폐기 한다면 환자와 병원에 모두 경제적인 피해는 상당할 것이다. 따라서 환자가 사용한 모든 물품은 일정기간 동안 환 자 본인만이 쓰도록 지시하고 있고 환자가 사용한 폐 기물 또한 일정기간 따로 폐기물보관실에서 자연붕괴 하여 허용기준치 이하가 되면 폐기하도록 하고 있다.

\section{2) 폐기물 관리 현황}

폐기물 보관 후 자체폐기 하는 곳은 4 개의 병원이었고 위탁폐기는 1곳으로 조사되었다. 이는 앞서 설명한데로 일정한 시일만 지나면 일반폐기물과 같이 처리 할 수 있 는 특성 때문에 경비 절감 차원에서 각 병원에서 자체처 리 하고 있는 것으로 보이고 특히 환자가 입는 환의와 시 트는 구강이나 피부에 직접 닿기 때문에 오염이 많이 되 어 세탁을 따로 필요로 한다. 따라서 폐기방법은 자연붕 괴 후 대부분 재사용을 하고 있었다. 하지만 $\mathrm{E}$ 병원만 1 회 용 환의와 시트를 사용 중인 것으로 파악 되었다(Table 5).

Table 5. Management Status of Waste and Wastewater

(해당되는 곳에 $\vee$ 표시)

\begin{tabular}{|c|c|c|c|c|c|c|}
\hline 특 성 & 구 분 & A병원 & B병원 & C병원 & D병원 & E병원 \\
\hline \multirow{2}{*}{ 1. 폐기물 폐기 방법 } & 자체 & $y$ & & $y$ & $\gamma$ & $y$ \\
\hline & 위탁 & & $Y$ & & & \\
\hline \multirow{2}{*}{$\begin{array}{l}\text { 2.환의 및 시트 } \\
\text { 폐기 방법 }\end{array}$} & 폐기 & & & & & 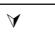 \\
\hline & 재사용 & $Y$ & $Y$ & $Y$ & $Y$ & \\
\hline \multirow{2}{*}{ 3. 음식물 폐기 방법 } & 분쇄 & 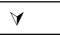 & $Y$ & & $Y$ & $y$ \\
\hline & 폐기 & & & 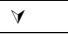 & & \\
\hline \multirow{2}{*}{$\begin{array}{l}\text { 4. 수저와 젓가락 사 } \\
\text { 용 }\end{array}$} & 개인 & 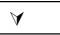 & $Y$ & & $Y$ & $y$ \\
\hline & 공용 & & & $Y$ & & \\
\hline \multicolumn{2}{|c|}{ 5.1회당 평균 폐기물 수거량 $(\mathrm{L})$} & 20 & 50 & 10 & 15 & 35 \\
\hline \multicolumn{2}{|l|}{ 6.폐수탱크 용량(톤) } & 250 & 150 & 150 & 200 & 120 \\
\hline \multicolumn{2}{|c|}{$\begin{array}{l}\text { 7.폐수탱크 1기 만수시 평균기 } \\
\text { 간(일) }\end{array}$} & 120 & 160 & 120 & 120 & 100 \\
\hline \multicolumn{2}{|c|}{$\begin{array}{l}\text { 8. 폐수 탱크 배수시 선량기준 } \\
\left(\mathrm{Ba} / \mathrm{m}^{3}\right)\end{array}$} & $3 \times 10^{4}$ & $3 \times 10^{4}$ & $3 \times 10^{4}$ & $3 \times 10^{4}$ & $3 \times 10^{4}$ \\
\hline
\end{tabular}

폐기물 중 중요 문제가 바로 음식물 폐기방법이다. 음식물 분쇄기가 없는 병원에서는 아무런 조치도 행 하지 않고 그대로 폐기시키는 경우가 있고 일정기간 보관 후 폐기한다하여도 중간에 생기는 악취와 해충 의 발생으로 인해 폐기물실 관리에 적잖은 어려움이 있다. 음식물 폐기방법에 대해 조사한 결과 $\mathrm{C}$ 병원을 제외한 모든 곳이 분쇄기를 이용하여 음식을 분쇄하 여 폐수탱크로 흘려 보내도록 설계되어 있었다. 반면 $\mathrm{C}$ 병원은 환자가 먹다 남은 음식물을 아무런 조치도 없이 일반 음식물과 같이 폐기 시켰으며 수저와 젓가 락을 일반 환자들과 공용으로 사용하고 있었다. 이는 치료병실관리가 형식적으로 시행되고 있는지를 잘 보 여주는 단적인 예라 할 수 있다. 따라서 C병원은 폐기 물관리에 있어 한 치의 소홀함이 없도록 좀 더 적극적 인 자세가 요구된다.

\section{3) 폐수 관리 현황}

환자가 욕실이나 화장실에서 사용한 물도 곧바로 정화조로 보내어지면 환경오염의 문제가 있기 때문에 일정기간 동안 폐수탱크에 보관하여 배수 시 원자력 안전위원회고시 '방사선방호등에 관한 기준' 제6조에 의해 배수중의 배출허용농도 $3 \times 10^{4} \mathrm{~Bq} / \mathrm{m}^{3}$ 이하가 될 때 배수토록 하고 있다막. 각 병원들 조사결과 폐수탱 크 1 기 만수 시 평균기간은 약 120 일 정도였고, 법정허 용기준치 이하가 됐을 때 배수하고 있었다.

\section{4. 방사성 옥소 투여 시 안전관리 시행 현황}

\section{1) 방사성옥소 운반 시 피폭선량}

131I 캡슐을 $2 \mathrm{~cm}$ 두께 납 용기에 넣어 손수레로 운반 할 때 운반자가 받을 수 있는 피폭선량은 다음과 같다.

$\operatorname{Hp}(10)=\quad \mathrm{fe} \times \mathrm{Ac} \times \mathrm{T} \times \mathrm{Dt}$ $r^{2}$

· fe: 심부선량율 환산계수 $\left(\mathrm{mSv}_{\mathrm{v}} \cdot \mathrm{m}^{2} \cdot \mathrm{MBq}^{-1} \cdot \mathrm{hr}^{-1}\right)$

- Ac: ${ }^{131} \mathrm{I}$ 의 방사능 $(\mathrm{MBq})$

- T: 운반소요시간(hr)

- Dt : 두께 $\mathrm{t} \mathrm{cm}$ 의 납 차폐체의 심부선량 감쇠율

•r: 운반자와 납 용기의 거리 
따라서 방사성옥소 운반 시 운반자와 납 용기 사이 의 거리를 멀리할수록 운반자가 받는 피폭선량은 낮 아질 수 밖에 없다. 그러나 C병원은 외부피폭 방호원 칙인 선원과 거리를 두지 않고 납 용기 자체만 손으로 들고 운반하여 피폭관리가 제대로 지켜지지 않고 있 음을 알 수 있었다(Table 6).

Table 6. Safety Management of Radioactive lodine Uptake

(해당되는 곳에 $\vee$ 표시)

\begin{tabular}{|c|c|c|c|c|c|}
\hline 문 항 & $\begin{array}{l}\mathrm{A} \\
\text { 병원 }\end{array}$ & $\begin{array}{l}\mathrm{B} \\
\text { 병원 }\end{array}$ & $\begin{array}{l}\mathrm{C} \\
\text { 병원 }\end{array}$ & $\begin{array}{l}\mathrm{D} \\
\text { 병원 }\end{array}$ & $\begin{array}{l}E \\
\text { 병원 }\end{array}$ \\
\hline \multirow{2}{*}{$\begin{array}{l}\text { 1.방사성옥소 운반시 } 2 \mathrm{~cm} \text { 두께 납 용기에 } \\
\text { 넣어 (1) 운반용 손수레로 운반한다. } \\
\text { (2) 납 용기만 들고 운반한다. }\end{array}$} & $r$ & 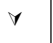 & & $\gamma$ & $\gamma$ \\
\hline & & & 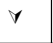 & & \\
\hline \multirow{2}{*}{$\begin{array}{l}\text { 2.방사성옥소 투여시 종사자가 } \\
\text { (1) 시범을 보인 후 환자가 먹는다. } \\
\text { (2) 직접 먹인다. }\end{array}$} & $r$ & 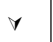 & & $y$ & 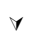 \\
\hline & & & $r$ & & \\
\hline \multirow{2}{*}{$\begin{array}{l}\text { 3. 옥소 투여시 방호도구를 (1) 착용한다. } \\
\text { (2) 착용하지 않는다. }\end{array}$} & & 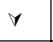 & $r$ & $\gamma$ & $\gamma$ \\
\hline & $r$ & & & & \\
\hline \multirow{2}{*}{$\begin{array}{l}\text { 4. 옥소투여시 환자에게 방사성옥소의 주 } \\
\text { 의사항에 대해 (1) 설명한다. } \\
\text { (2) 설명하지 않는다. }\end{array}$} & $r$ & $v$ & $\gamma$ & $r$ & $r$ \\
\hline & & & & & \\
\hline \multirow{2}{*}{$\begin{array}{l}\text { 5.병실 사용시 환자가 밖으로 나오지 않도 } \\
\text { 록 (1) 설명한다. } \\
\text { (2) 설명하지 않는다. }\end{array}$} & r & & & $r$ & r \\
\hline & & $v$ & $\gamma$ & & \\
\hline \multirow{2}{*}{$\begin{array}{l}\text { 6. 응급 발생시 조치방법에 대해 } \\
\text { (1) 설명한다. } \\
\text { (2) 설명하지 않는다. }\end{array}$} & $r$ & 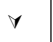 & $r$ & $y$ & r \\
\hline & & & & & \\
\hline \multirow{2}{*}{$\begin{array}{l}\text { 7.병실 사용시 쓰레기는 반드시 전용폐기 } \\
\text { 물 통에 버리도록 (1) 설명한다. } \\
\text { (2) 설명하지 않는다. }\end{array}$} & $r$ & $v$ & $r$ & $r$ & $r$ \\
\hline & & & & & \\
\hline
\end{tabular}

\section{2) 방사성옥소 투여 시 주의사항}

암 환자는 심리적으로 매우 불안하고 예민하다. 특 히 옥소치료병실에 입원해야 하는 환자의 경우는 홀 로 몇 일을 보내야 하기 때문에 입원 당시 받는 심적 스트레스는 상당하다. 따라서 방사성옥소를 투여 할 때 종사자는 환자에게 치료병실을 사용하면서 주의사 항에 대해 설명의 의무를 다해야 한다. 어떤 환자의 경우는 소화가 잘 되지 않는 환자도 있어 먹었던 방사 성옥소를 토해내는 경우도 있고 설명을 정확하기 전 달받지 못한 환자는 캡슐을 깨물어 먹는 경우도 있다. 따라서 환자에게 심리적 부담감을 주지 않는 범위에 서 가능한 쉽고 간결하게 설명을 해줘야 한다.
또한, 현재 방사성옥소 투여 시 대부분 병원들이 종 사자가 시범을 보인 후 환자가 먹게끔 하고 있다. 간 혹 옥소를 먹기 곤란한 환자의 경우에는 종사자가 직 접 먹이는 경우도 발생한다. 하지만 $\mathrm{C}$ 병원은 옥소 투 여 시 모든 환자에게 종사자가 직접 옥소를 먹이고 있 었고, $\mathrm{A}$ 병원은 종사자가 방호도구를 착용하지 않는 것 으로 조사되어 종사자 피폭관리에 문제가 있음을 알 수 있었고, B병원과 C병원에서는 옥소투여를 받은 환 자가 병실 밖으로 나오지 않도록 설명하지 않아 일반 인에 대한 피폭관리도 되지 않음을 알 수 있었다(Table 6). 따라서 현 실태에 대해 면밀히 조사하여 아주 적은 피폭이라도 인체에 영향을 미칠 수 있기 때문에 제대 로 된 관리가 수행되어야 할 것이다.

\section{5. 치료병실 청소 시 안전관리 시행현황}

방사선 관리구역은 방사선 안전을 위해 사람이나 물품의 출입을 제한하거나 안전수칙을 준수할 것을 요구할 수 있는 구역으로 이해할 수 있다. 즉, 방사선 방호 활동이 적극적으로 실시되는 구역으로 방사성옥 소를 사용하는 치료병실은 일반인의 출입을 제한하게 된다. 따라서 치료병실관리에 있어서 치료병실 청소는 일반 병실과 달리 환자에서 나온 소변, 땀, 침, 가검물 등이 병실내부를 오염시키기 때문에 제염작업이 필요 하고 방사성폐기물의 수거 및 보관 관리도 필요 하기 때문에 방사선 작업종사자 교육을 받은 사람이 관리 해야 한다.

하지만 조사결과 모든 문항에서 C병원은 일반병실 과 똑같이 관리되고 있다(Table 7). 청소도구는 치료병 실과 일반병실 구분 없이 같이 사용하고 있었고 손과 신발이 오염되지 않도록 장갑이나 덧신을 착용하지 않고 작업하였다. 그리고 A병원을 제외한 나머지 병원 은 마스크가 비치되어있어도 착용하지 않았으며 A병 원과 $\mathrm{C}$ 병원은 청소 시 주기적으로 교대근무 하지 않 고 있었다. 물론 종사자 1 인이 계속 작업하여도 선량 한도를 초과하는 일은 없을 것이다. 더욱이 표면오염 이 높다고 하여 피폭선량이 비례해 증가하는 것은 아 니므로 확대해석할 필요는 없다. 하지만 물체 표면의 방사능 오염은 공기오염을 유발하기도 하고 작업자의 손과 입을 통해 체내로 들어가 내부피폭의 원인이 되 기 때문에 일정 기준치 이하로 유지해 피폭관리에 힘 
"Journal of the Korean Society of Radiology, Volume 6, Number 5"

쓰도록 해야 한다 ${ }^{[9]}$.

치료병실은 옥소치료를 받기 위한 전용병실로 방사 선 관리구역이다. 따라서 핵의학과가 아닌 병동에서 관리하면서 생기는 오류들을 다시 한번 되짚어 보고 관리 한다면 치료병실 안전관리에 보다 효율적일 것 이다.

Table 7. Safety Management of Therapy Room Cleaning (해당되는 곳에 $\vee$ 표시)

\begin{tabular}{|c|c|c|c|c|c|}
\hline 문 항 & $\begin{array}{l}\mathrm{A} \\
\text { 병원 }\end{array}$ & $\begin{array}{l}\mathrm{B} \\
\text { 병원 }\end{array}$ & $\begin{array}{l}\mathrm{C} \\
\text { 병원 }\end{array}$ & $\begin{array}{l}\text { D } \\
\text { 병원 }\end{array}$ & $\begin{array}{l}E \\
\text { 병원 }\end{array}$ \\
\hline \multirow{2}{*}{$\begin{array}{l}\text { 1.청소 시 덧신을 (1) 착용한다. } \\
\text { (2) 착용하지 않는다. }\end{array}$} & $\gamma$ & & & $\gamma$ & 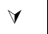 \\
\hline & & $y$ & $\gamma$ & & \\
\hline \multirow{2}{*}{$\begin{array}{l}\text { 2.청소 시 마스크를 (1) 착용한다. } \\
\text { (2) 착용하지 않는다. }\end{array}$} & 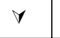 & & & & \\
\hline & & $\nabla$ & $\gamma$ & $\gamma$ & $y$ \\
\hline \multirow{2}{*}{$\begin{array}{l}\text { 3.청소 시 가운을 벗고 (1) 청소한다. } \\
\text { (2) 청소하지 않는다. }\end{array}$} & & $v$ & & & $v$ \\
\hline & $r$ & & 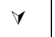 & 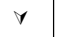 & \\
\hline \multirow{2}{*}{$\begin{array}{l}\text { 4.오염제거 시 손이 오염되지 않도록 } \\
\text { 보호장갑을 (1) 착용한다. } \\
\text { (2) 착용하지 않는다. }\end{array}$} & $r$ & 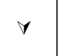 & & $r$ & 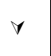 \\
\hline & & & $r$ & & \\
\hline \multirow{2}{*}{$\begin{array}{l}\text { 5. 치료병실 전용 청소도구가 (1) 있다. } \\
\text { (2) 없다. }\end{array}$} & $r$ & 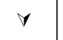 & & 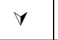 & 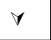 \\
\hline & & & $\gamma$ & & \\
\hline \multirow{2}{*}{$\begin{array}{l}\text { 6.청소는 주기적으로 다른 종사자와 } \\
\text { 교대로 (1) 시행한다. } \\
\text { (2) 시행하지 않는다. }\end{array}$} & & v & & $r$ & $r$ \\
\hline & $r$ & & $r$ & & \\
\hline \multirow{2}{*}{$\begin{array}{l}\text { 7.치료병실 청소는 좃사자 교육을 받 } \\
\text { 은 사람이 (1) 시행한다. } \\
\text { (2) 시행하지 않는다. }\end{array}$} & $r$ & v & & $y$ & $\gamma$ \\
\hline & & & $r$ & & \\
\hline \multirow{2}{*}{$\begin{array}{l}\text { 8.청소종료 후 반드시 손과 신발의 오 } \\
\text { 염여부를 (1) 확인한다. } \\
\text { (2) 확인 하지 않는다. }\end{array}$} & $r$ & & & $r$ & $Y$ \\
\hline & & 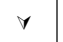 & $r$ & & \\
\hline \multirow{2}{*}{$\begin{array}{l}\text { 9. 방사성 폐기물 운반 시 전용카트에 } \\
\text { (1) 운반한다. } \\
\text { (2) 운반 하지 않는다. }\end{array}$} & 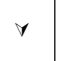 & $\checkmark$ & & 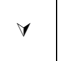 & $\gamma$ \\
\hline & & & 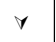 & & \\
\hline \multirow{2}{*}{$\begin{array}{l}\text { 10. 청소에 사용된 청소도구들은 따로 } \\
\text { (1) 보관한다. } \\
\text { (2) 보관하지 않는다. }\end{array}$} & $\nabla$ & $\checkmark$ & & $y$ & $y$ \\
\hline & & & $r$ & & \\
\hline
\end{tabular}

\section{6. 환자 퇴원 시 안전관리 시행현황}

\section{1) 퇴원 시 유효선량}

개봉선원을 사용하는 의료기관에서 진료의 목적으 로 방사성동위원소를 투여 받은 환자로부터 체내에 잔류하는 방사성동위원소가 원자력안전위원회 고시
제2012-37호에 따라 고시하는 수량을 초과하는 환자는 일반환자와 격리 수용하고 있다. 진료환자를 격리하기 위한 ${ }^{131} \mathrm{I}$ 의 투여량은 $1,100 \mathrm{MBq}$ (약 $30 \mathrm{mCi}$ )이상이고 퇴 원 시 기준유효선량이 $5 \mathrm{mSv}$ 이하 일 때 퇴원이 가능 하며 환자의 퇴원으로 인해 다른 개인의 유효선량이 $1 \mathrm{mSv}(0.1 \mathrm{rem})$ 를 초과할 경우에는 ALRARA지침서를 제 공해야 하며 수유중인 신생아 또는 어린이는 유효선 량이 $1 \mathrm{mSv}(0.1 \mathrm{rem})$ 를 초과하지 않도록 해야 한다.

따라서 각 병원별 퇴원 시 유효선량기준에 대해 조 사 한 결과 모든 병원이 유효선량기준에 적합하도록 관리 하고 있었다(Table 8). 다만, 각 병원들이 퇴원 시 기준선량을 정확히 알고 잘 지킨다고 하였으나 모든 환자에게 기준을 적용시켜서 퇴원시키는지는 알 수 없었다.

Table 8. Standard Effective Dose at Discharge

(unit: mSv)

\begin{tabular}{|c|c|c|c|c|c|}
\hline 구 분 & $\begin{array}{c}\mathrm{A} \\
\text { 병원 }\end{array}$ & $\begin{array}{c}\mathrm{B} \\
\text { 병원 }\end{array}$ & $\begin{array}{c}\mathrm{C} \\
\text { 병원 }\end{array}$ & $\begin{array}{c}\mathrm{D} \\
\text { 병원 }\end{array}$ & $\begin{array}{c}\mathrm{E} \\
\text { 병원 }\end{array}$ \\
\hline 퇴원 시 유효선량 기준 & 5 & 5 & 5 & 5 & 5 \\
\hline
\end{tabular}

\section{2) 퇴원 시 안전관리}

방사성옥소는 특성상 침샘이나 땀으로도 배출되기 때문에 환자가 먹다 남은 음식과 사용한 개인위생용 품은 상당량이 오염 되어 있다. 이에 옥소치료환자가 퇴원 후에는 ALARA개념하에서 다른 사람에 게 피폭을 줄일 수 있는 방안에 대해 다음과 같이 설명의 의무를 다해야 한다.

(1) 최소 2일은 소아나 임산부와 접촉하지 않는다.

(2) 최소 2 일은 다른 사람과 거리를 둔다.

(3) 최소 첫날은 혼자 잔다.

(4) 최소 첫날 대중교통을 이용하지 않는다.

(5) 최소 2 일은 다른 사람과 2 시간 이상 자동차를 같이 타지 않는다.

(6) 최소 2 일은 전용화장실을 사용한다.

(7) 최소 2일은 변기 사용 후 물은 2 3회 내린다.

(8) 최소 3 일은 일회용 식기를 사용하거나 다른 사람의 식기 와 분리 세척한다. 
(9) 구강접촉을 삼가고 3 일간 입에 닿는 물건은 다른 사람과 따로 사용한다.

(10) 최소 3 일간 옷은 다른 사람 옷과 분리하여 세탁한다 ${ }^{[10]}$. 따라서 종사자는 환자에게 퇴원 후 주의사항에 대해 설 명하고 실천 할 수 있도록 해야 한다.

\section{III. 고찰}

방사성옥소를 이용한 갑상선 암의 치료는 지난 수 십년 동안 사용되어 왔으며 많은 치료효과를 보이면 서 앞으로 지속적으로 사용되어 질 전망이다. 현재 옥 소 치료병실 수는 2010 년 기준 124 개의 치료병실이 운 영되고 있다. 몇 년 전에 비해 많이 증가한건 사실이 나 아직도 부족한 실정이다. 치료병실을 개설하려면 많은 규제를 받는다. 즉 관련규정에 적합하도록 병실 시설과 방사능 차폐, 기타 폐수 및 환기관을 설치 해 야 하며 그 비용은 1 억 5 천에서 2 억 이상 든다. 따라서 경제적인 비용이 많이 들다 보니 각 병원에서는 퇴원 기준에 맞지 않는 환자도 편법으로 퇴원시키면서 병 실회전율을 높이고 있는 실정이다. 또한 치료병실이 부족하다 보니 한 두 번의 고용량 옥소치료를 받아야 할 환자를 $30 \mathrm{mCi}$ 이하로 여러 번 행하는 경우도 있어 환자는 심리적 고통과 불편함을 감수 할 수 밖에 없다.

이로 인해 몇 몇 연구 결과에 의하면 치료병실 수 를 무작정 늘리기 보단 환자를 보다 빨리 퇴원 시킬 수 있는 방법과 관련 규정들을 좀 더 완화 시킬 수 있 는 방안이 필요하다고 보고되고 있고 그 방안으로는 배수중의 배출허용농도를 줄이는 방법과 환자 퇴원 시 유효선량을 줄이는 방안에 대해 보고되고 있다.

하지만 중요한건 환자대비 치료병실수의 많고 적 음을 떠나 병실증설과 병실 회전율을 논의하기에 앞 서 치료병실의 올바른 관리가 무엇보다 선행되어야 할 것이다. 올바른 관리가 되지 않고 있는데 증설만 한다면 과연 그것이 옳은 것인지 생각해 볼 필요가 있 다. 즉, 제대로 된 치료병실관리가 있음으로써 차후 생 기는 환자와 주변인과 종사자에 대한 피폭, 그리고 환 경적인 측면의 문제까지 예방하고 고려 할 수 있을 것 이고 올바른 치료병실관리가 먼저 선행된 후에 치료 병실의 증설이 되어도 늦지 않을 것이다.

\section{IV. 제안}

본 조사는 일부 대학병원 옥소치료병실 관리 실태 를 한번 되짚어 보고자 하였다. 대부분의 병원들이 치 료병실관리 있어서 법정제한이 있는 사항에 대해서는 안전기준을 모두 잘 지켜지고 있음을 확인 하였다. 하 지만 그 외의 안전관리 측면에서는 소홀히 관리하는 면이 적지 않게 노출 되었다. 그렇다면 방사선안전관 리를 강화하기 위해 법적 규제를 강화하는 것도 하나 의 대안이 될 수도 있겠으나 무작정 법정규제만 한다 면 결코 올바른 관리가 이루어지진 않을 것이다. 따라 서, 옥소치료병실의 올바른 관리가 이루어지기 위해 다음과 같이 제안한다.

첫째, 환자와 종사자의 방사선피폭관리에 대한 안 전관리 교육을 강화하여 방사선피폭관리에 힘쓰도록 해야 한다. 특히 아주 적은 양의 피폭이라도 방사선의 영향 중 확률적 영향까지 배제 할 순 없기 때문에 한 치의 소홀함이 없도록 관리되어야 할 것이다. 둘째, 병 원들이 치료병실을 운영하면서 기타 많은 비용이 요 구되기 때문에 현실적인 병실수가가 적용될 수 있도 록 관련 기관단체 등의 검토가 필요하다. 셋째, 현재 사용하고 있는 1 인실 병실을 2인실로 사용하도록 한 다. 그렇다면 종사자의 업무 부담을 최소화 할 수 있 을 것이고 치료를 기다리는 환자들의 대기기간도 줄 어들 것이며 환자의 고립감과 두려움도 해소 시킬 수 있을 것이다.

마지막으로, 각 병원간 치료병실관리에 대한 정보 를 서로 교류 함으로써 개선사항을 보완하여 효율적 인 관리를 기대 할 수 있을 것이다.

\section{Reference}

[1] 오헌진 등, 의료기관 방사선관계종사자 내부피폭실시기준 개발, 식품의약품안전청 연구보고서, 7, pp.617 621, 2003.

[2] 국가 암 정보센터, 국가 암 등록 통계, 2009

[3] 박민재 등, 우리나라에서 방사성옥소입원치료 관리 최적화, 대한 핵의학회지, Vol 42, No. 4, 2008.

[4] 소용선 등, 그레이브스 갑상선기능항진증 환자의 방사성옥소 치료시 실제 유효반감기의 측정, 대한핵의학회지, 1996.

[5] 원자력안전위원회 고시, 의료분야의 방사선 안전관리에 관한 
기술기준, 제2012-37호 제12조(진료환자의 격리수량).

[6] 한국동위원소협회, 방사선이용통계자료, 2010.

[7] 임청환, 김승철, 방사성물질을 이용한 치료의 안전관리 고찰, 한국콘텐츠학회논문지, Vol.8 No. 11, 2008.

[8] 원자력안전위원회고시, 방사선방호 등에 관한 기준, 제6조 방사성옥소의 배출관리기준.

[9] 한국원자력아카데미, 방사선교육교재, pp20, 2012.

[10] 배상균, 갑상선 질환의 방사성옥소 치료, 대한핵의학회 연수강좌, pp11 18, 2001. 